\title{
Battle of the Sexes: How Sex Ratios Affect Female Bargaining Power
}

\author{
ERWIN BULTE \\ Wageningen University \\ QIN TU \\ Beijing Normal University \\ JOHN LIST \\ University of Chicago
}

\section{Introduction}

The effect that sex ratios (the ratio of men to women in the population) have on modern societies has been of interest to scholars at least since Groves and Ogburn (1928). Early empirical work focused on linking sex ratios to marriage outcomes and fertility rates (see, e.g., Cox 1940; Easterlin 1961). The seminal work of Becker $(1973,1974)$ advanced the literature in a new direction by providing several unique theoretical predictions, inducing economists to delve into the economic implications of changing sex ratios.

Several recent creative empirical examples highlight such efforts. Angrist (2002) exploited intertemporal variation in migration flows to examine the effect of sex ratios on family structure and economic variables in the first half of the twentieth century in the United States. He documents that high sex ratios caused men to marry sooner, improved female marriage prospects, lowered female labor supply, and increased the well-being of children. More recently, Abramitzky, Boustan, and Eriksson (2012) make use of the large shock that World War I caused to the number of French men to show that the sex ratio has a strong impact on marriage market outcomes and on assortative matching - men are less likely to "marry down" in regions with lower sex ratios. In the context of China, Wei and Zhang (2011a, 2011b) demonstrate that high sex ratios encourage entrepreneurship and that parents of male offspring respond to more intense competition for girls on marriage markets by accumulating more savings.

While such studies have proven quite important in extending our understanding of the economic implications of sex ratios, what is less clear is the underlying mechanism at work. Such results are consistent with the hypothesis 
that higher sex ratios improve female bargaining power. Chiappori, Fortin, and Lacroix (2002), for example, developed a collective model of (efficient) intrahousehold bargaining and treat the sex ratio as an exogenous "distribution factor" affecting the relative bargaining power of females (and the ensuing distribution of gains from marriage). If women are scarce, their weight in the decision process increases. Becker's work has a similar underlying channel of influence.

Angrist $(2002,997)$ carefully interprets his research in this spirit, noting that his results are "broadly consistent with theories where higher sex ratios increase female bargaining power in the marriage market." Yet, there are alternative interpretations of such findings, embedded in simple theoretical constructs. For example, if sex ratios are high, women will anticipate an "easier" marriage market and respond by investing less in developing independent means of support (education), so their future earnings are modest, and in equilibrium they supply less labor. Men, in contrast, face a much more competitive marriage market and invest greater amounts. The marginal value product of their labor increases as a result, and they supply more labor in equilibrium. In such a scenario, the bargaining position of women need not change, but labor supplied by men and women differs across high and low sex ratio states.

To provide a first glimpse at whether sex ratios and bargaining power are linked, we make use of spatial variation in sex ratios across China. Exogenous variation exists because the one-child policy (OCP) does not apply to all ethnic groups (or at least is not equally restrictive), and the stringency of fertility regulation is a determinant of local sex ratios (see below). As part of affirmative action policies, "ethnic minorities" are allowed to have more children than stipulated by the OCP, and for some groups the number of children is not restricted. We then overlay an artifactual field experiment and an individual-level survey to test whether bargaining power varies across space in a manner that is consonant with theory. When comparing the various proxies of bargaining power, we find evidence that it does: there is a robust positive correlation between sex ratios and female bargaining power, and the magnitude of this effect is economically significant.

We view these results as not only providing structure to the extant reducedform results in the literature but also complementing the rapidly growing literature on female empowerment. At the level of societies, empowerment affects priority setting in policy making (Chattopadhyay and Duflo 2004), and at the level of individual households it affects the bundle of consumption goods purchased. Women appear to have stronger preferences for child schooling and health outcomes and for household shared goods (e.g., Senauer, Garcia, and Jacinto 1988; Thomas 1990, 1993; Hoddinott and Haddad 1995; 
Lundberg, Pollak, and Wales 1997; Duflo 2003; Gitter and Barham 2008). In contrast, women are less likely to spend resources on alcohol and tobacco (Hoddinott and Haddad 1995).

Existing analyses of the determinants of bargaining power focus on resources exogenous to labor supply (which arguably is a function of the intrahousehold distribution of power). Such resources include nonlabor income (Thomas 1990), current assets (Doss 1999), inherited assets (Quisumbing 1994), dowries (Brown 2009), and transfers or welfare receipts (Lundberg et al. 1997). They may also include relative education levels (Gitter and Barham 2008) and access to, for example, certain financial services (Ashraf, Karlan, and Yin 2010). An important component of most interventions to promote female empowerment consists of providing women with control over specific resources, for example, via targeted transfers. Our results suggest that the high sex ratios are another channel at work leading to changes in relative bargaining power and, thus, to changes in economic outcomes. This is important because identifying causal relationships not only advances our understanding of development, but it also improves our ability to tailor policies so that they successfully promote economic objectives.

The remainder of the article is organized as follows. In Section II we summarize the background of our research. Section III outlines how we measure the bargaining power. Section IV introduces our data and models, and Section $\mathrm{V}$ contains our empirical results. A concluding discussion is contained in Section VI.

\section{Background}

In countries such as India and China, high sex ratios are typically associated with the so-called missing women problem. Worldwide, some 65-100 million women are "missing" - a humanitarian and societal issue of first-order importance (Sen 1992; Klasen and Wink 2002; Bulte, Zhang, and Heerink 2011). In recent decades, sex ratios have increased steadily in China; the country with the largest number of missing women. Klasen and Wink (2002) estimated that the number of Chinese missing women rose from 34.6 million in the 1980s to 40.9 million in the 1990s (or from 6.3\% to 6.7\%). Qian (2008) documents how the fraction of males in cohorts born during 19702000 increased from $51 \%$ to $57 \%$. Overall, the Chinese sex ratio at birth was 1.21 in 2008 , which is clearly distinct from the natural ratio of approximately 1.05 (NBS 2009). Wei and Zhang (2011b, 1) conclude that "roughly one out of every nine young men today has no realistic hope to get married, mathematically speaking," and that in some provinces no less than one out of six men faces this plight. 
While distorted sex ratios are by no means confined to China, it has been documented that the Chinese OCP has contributed significantly to biased sex ratios. For example, Bulte et al. (2011) argue that the OCP explains about half of the Chinese sex gap. The OCP restricts fertility, even if it does not imply that all households can have only one child. ${ }^{1}$ Restricted fertility, combined with a strong preference for male offspring (to work on the farm or to provide security for old age or "to carry the family name forward"), implies a strong incentive for sex-selective abortion (even if that is illegal according to Chinese law). Ultrasound technology — enabling sex detection in utero-is widely available, even in remote areas.

Our identification strategy rests on exogenous variation in sex ratios over space (and, to some extent, over time). Exogenous variation exists because the OCP does not apply to all ethnic groups (or at least is not equally restrictive). As part of affirmative action policies, "ethnic minorities" are allowed to have more children than stipulated by the OCP, and for some groups the number of children is not restricted at all. Li and Zhang (2007) use the fact that Han Chinese are subject to stricter controls on family planning than ethnic minority groups, to probe the issue of population growth and economic performance. Bulte et al. (2011) use spatial variation in the share of ethnic minorities to obtain exogenous variation in the stringency of the OCP, allowing an examination of the impact of the OCP on sex ratios at birth. As expected, they document a positive relation between sex ratios and the share of Han Chinese - sex ratios are highest in regions where the great majority of the population is subject to the OCP.

In spite of considerable (rural-urban) migration flows, variation in the imbalance on local marriage markets remains. Specifically, in areas where ethnic minorities are relatively abundant, the OCP restricts the fertility of a smaller share of the population, and sex-selective abortion occurs less frequently. Sex ratios are less distorted - the marriage market is more balanced-when the share of Han Chinese in the local population is lower (Bulte et al. 2011).

Our approach is to randomly sample households in counties with high and low shares of ethnic minorities and compare the bargaining power of the spouses across such localities. If female scarcity empowers women, then women should have more bargaining power in areas where the share of ethnic minorities is relatively low. For our identification strategy to be credible,

\footnotetext{
${ }^{1}$ The OCP is a set of regulations restricting family size and the timing of marriage and childbearing. The one-child rule applies only to urban residents and government employees (even if exceptions exist, e.g., because the first child is disabled or because both parents are single children themselves). In many rural areas households can have a second child after 5 years (sometimes only when the first child is a girl). As explained in the text, ethnic identity also matters.
} 
four conditions have to be satisfied. First, our results should not confound the effect of local female scarcity with interethnic cultural factors. For that reason we restrict the analysis to couples in which both spouses are Han Chinese. Second, the marriage market should be sufficiently "local"-local differences in sex ratios should imply local variation in marriage market imbalances. This condition is also satisfied. According to the latest census, no less than $87 \%$ of the people marry within their own county. ${ }^{2}$ This statistic reflects that many marriages are arranged. Third, marriage should not be endogamous (i.e., within ethnicity). Interethnic marriage provides Han males with access to non-Han women (even if, as mentioned, our sample is confined to couples in which both partners are Han), so that a greater share of ethnic minorities alleviates the scarcity of partners for Han men. Wei and Zhang (2011b) demonstrate that marriage across ethnic groups is commonly observed. ${ }^{3}$ Finally, the scarcity of women should affect the threat point of spouses within intrahousehold bargaining problems. This might happen, for example, if disappointed women can credibly threaten to leave their husband. While divorce is not common in rural China, it does occur.

We collected data in 16 villages in two counties: Lipu county ( 156 couples) and Quanzhou county (146 couples). The share of ethnic minorities in Lipu is $19.8 \%$, and in Quanzhou it is $4.7 \%$. This variation may translate into divergent sex ratios. In figure 1 we summarize sex ratios for different age cohorts, for both Lipu and Quanzhou. When computing sex ratios, one should use a constant age difference window (e.g., the ratio of males of age $a$ to females of age $a-x$, where $x$ is constant). In what follows we set $x=0$, so we consider the numbers of males and females in a specific age cohort.

A few observations are noteworthy. First, sex ratios for older cohorts are low-below 1-reflecting relatively high natural mortality rates for older men. Second, for pre-OCP cohorts older than the 20-24 age group, sex ratios are very similar for both counties and appear in excess of natural sex ratios (approximately 1.05). Note that somebody in the 20-24 age group was born between 1976 and 1980, as figure 1 is based on 2000 census data. Third, and most important, sex ratios for Lipu and Quanzhou are very different for co-

\footnotetext{
${ }^{2}$ We find the same pattern in our data: $85 \%$ of our respondents came from the same county as their spouse.

${ }^{3}$ While the incidence of interethnic marriages is, not surprisingly, lower than what would occur under random mixing of partners, the share of interethnic marriages is as high as $13 \%$ of all marriages in some provinces (details available on request). Unfortunately we do not have data on interethnic marriage rates at the village level. Note that Angrist (2002) requires the opposite condition-for his identification strategy to work he needs sufficiently strong preferences for endogamous marriage within immigrant communities.
} 


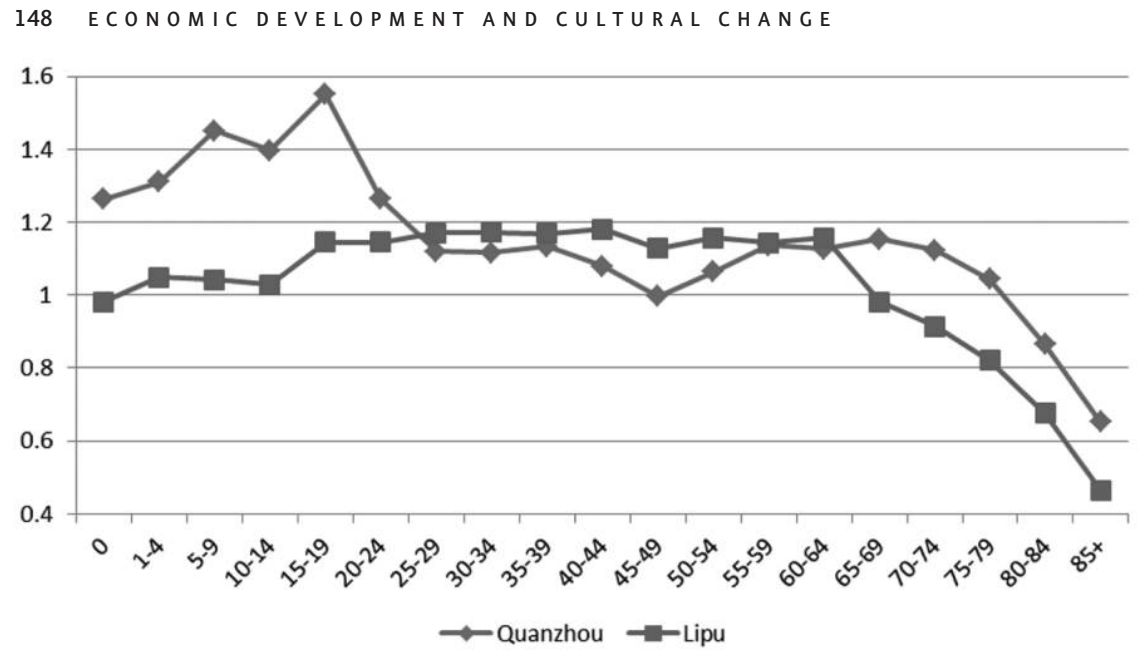

Figure 1. Sex ratios of Lipu and Quanzhou for different age groups. Sex ratios are high when the one-child policy is in place (cohorts $0,20-24$ ), but only in areas where the share of ethnic minorities in the population is low. Source: Fifth national census in 2000. Color version available as an online enhancement.

horts born when the OCP was in place- cohort 15-19 years, and younger, in 2000. While extensively discussed in the late 1970s and early 1980 s, the OCP was implemented in our study region in 1983 . Children born in 1984 were 16 years old at the time of the census and 28 years old when we collected our data. We use age 28 as an important threshold, distinguishing between cohorts born before and after the OCP was implemented. In our empirical analysis we exploit both types of variation in sex ratios-between Lipu and Quanzhou and between different age groups ( 5 years per cohort). To increase the variation in sex ratios, we draw our samples from a population in which the husband's age ranges from 20 to 50 years old.

Ideally we would also be able to show that the Han Chinese are obeying the OCP in Lipu and Quanzhou in approximately the same way-decomposing the variation in sex ratios to different ethnic groups. Unfortunately we lack county-level data on fertility per ethnic group. However, other data do suggest that Han Chinese in the two counties responded similarly to the OCP. A recent paper by Ding and Zhang (2013) argues that household responses to the OCP are affected by local livelihoods and that the local stringency of enforcement of the OCP varied with two key variables: (i) local population density and (ii) the existing sex ratio of the region. ${ }^{4}$ The share of people with

\footnotetext{
${ }^{4}$ Livelihoods matter because of concerns regarding old-age care, population density affects the collective willingness to enforce fertility restrictions, and existing sex ratios affect enforcement via incentives and punishment provided by higher levels of government (job prospects of local officials).
} 
a formal job (our proxy for livelihood) is similar in Lipu and Quanzhou (8.5\% and $8.9 \%$ in 2000, respectively), and population densities are similar as well (arable land per capita amounts to 1.4 and $1.2 \mathrm{mu}$, respectively). Moreover, from figure 1 is evident that the pre-OCP sex ratio is also comparable for these two counties (approximately 1.18 for the age cohort 25-29).

\section{Measuring Bargaining Power}

We combine survey and experimental techniques to measure bargaining power. Our first survey-based measure is subjective. We visited randomly selected couples at their house, physically separated the spouses, and asked both of them to indicate how the power regarding decisions around the house was split between the partners (in "tenths" of total decision power). Specifically, we asked the following question: "Generally speaking, regarding all affairs in your home, how many tenths of decision power do you think you have? The decision powers of you and your spouse should add up to 10." Obviously, the closer the sum of decision powers (as estimated by the spouses separately) is to 10 , the more agreement about the division of power within the household.

Our second measure of bargaining power is more objective: we asked which of the spouses is in charge of handling financial issues in the household. Specifically, we asked: "Generally speaking, who controls the use of money in the household?" If a respondent indicated that the woman is in charge, we coded that response as 1 . If the response was that the husband is in charge, it was coded as 0 . We gave the score of 0.5 when respondents indicated that both spouses jointly handle financial issues. Again, we asked male and female partners separately and averaged their responses to obtain a single household-level measure of bargaining power. This implies that we obtained an ordered variable with five possible outcomes: $0,1 / 4,1 / 2,3 / 4,1$.

Our third measure of bargaining power involves an artifactual field experiment (see Harrison and List 2004), following earlier work by Carlsson et al. (2012). We played simple allocation games with the spouses separately and collectively. We first took our respondents to separate rooms, provided each of them with a separate endowment of $¥ 100$ (but did not inform them that their spouse received the same amount), and asked them to divide the $¥ 100$ between the household and a public good. ${ }^{5}$ Note that $¥ 100$ equals approximately US $\$ 16$, which is a salient incentive for households in our sample. After that, the couple was brought together and given a joint endowment of $¥ 100$. We then asked the couple to collectively divide this joint

\footnotetext{
${ }^{5}$ Specifically, this concerned a donation to the well-known China Children and Teenagers' Fund.
} 
endowment between the household and a public good. The actual payment to the household was based on a random draw of one of these three choices (husband's, wife's, or joint). This approach allows us to probe to what extent "joint choices" reflect the preferences of individual partners. Specifically, if the joint choice resembles the choice of one of the spouses (and not that of the other), then we interpret this as evidence that this spouse's preferences dominate. ${ }^{6}$ We realize that various confounding factors may exist, and therefore we emphasize that the results should be interpreted with care. For example, Luhan, Kocher, and Sutter (2009) provide other reasons why individual versus pair decision making may produce different allocations.

\section{Data and Model}

Summary statistics of bargaining proxies, ethnic shares, sex ratios, and control variables are provided in table 1 . In terms of our first measure of bargaining power, on average the sum equals 10.9, which suggests that the average spouse is slightly optimistic about her (his) share of the power. For more than half of the couples $(50.5 \%)$ the sum is between 9 and 11 , and for almost $82 \%$ of the couples this sum is between 8 and 12. This apparent agreement across the spouses suggests that our procedure may be a simple way to gauge the division of decision power in couples. We adjusted the data by rescaling the sum of each couple to 10 and used the average estimate of the share of decision power residing with the woman, as indicated by both spouses, as our subjective measure of the wife's bargaining power. ${ }^{7}$

For our second bargaining measure, consistent with Carlsson et al. (2012) we document that, on average, husbands have more bargaining power and are slightly more likely to handle financial issues. However, we also document variation across the two counties. For our third bargaining measure, the partners of approximately one-third of the couples made similar individual allocations, and following Carlsson et al. (2012) we dropped these observations - no information on bargaining strength can be gleaned from them. We created two new dummy variables: "joint choice equals husband's choice" and "joint choice equals wife's choice." For households where the joint allocation coincided with the husband's preference, the former dummy takes the value 1 (and the second takes the value 0 ). The reverse is true for households where the joint choice equals the wife's preferences. In case the joint choice does not coincide with either preference, both dummies are coded as 0 . The

\footnotetext{
${ }^{6}$ For similar reasoning, in the domain of risk taking, refer to Bateman and Munro (2005).

${ }^{7}$ We obtain similar results if, instead, we use either of the separate appraisals by the spouses (details on request).
} 
TABLE 1

SUMMARY STATISTICS

\begin{tabular}{|c|c|c|c|c|c|c|c|c|}
\hline & \multicolumn{4}{|c|}{ All Data } & \multicolumn{2}{|c|}{ Lipu } & \multicolumn{2}{|c|}{ Quanzhou } \\
\hline & Mean & SD & Min & Max & Mean & SD & Mean & SD \\
\hline \multicolumn{9}{|l|}{ Dependent variable (bargaining proxy): } \\
\hline Survey-based bargaining power & 4.17 & 1.43 & 0 & 10 & 3.97 & 1.64 & 4.39 & 1.12 \\
\hline Woman handles finance & .48 & .29 & 0 & 1 & .38 & .27 & .58 & .28 \\
\hline Joint choice equals male choice & .41 & .49 & 0 & 1 & .40 & .49 & .43 & .50 \\
\hline Joint choice equals female choice & .39 & .49 & 0 & 1 & .36 & .48 & .41 & .49 \\
\hline \multicolumn{9}{|l|}{ Explanatory variable: } \\
\hline Sex ratio & 1.21 & .14 & 1.03 & 1.55 & 1.14 & .03 & 1.28 & .17 \\
\hline Age of husband & 34.3 & 5.72 & 23 & 54 & 33.5 & 4.98 & 35.2 & 6.32 \\
\hline Age difference & -2.04 & 2.93 & -19 & 7 & -2.19 & 3.21 & -1.88 & 2.59 \\
\hline Education husband & 8.90 & 2.37 & 0 & 16 & 9.16 & 2.14 & 8.62 & 2.56 \\
\hline Education difference & -.66 & 2.54 & -15 & 9 & -.48 & 2.42 & -.86 & 2.66 \\
\hline Have son (dummy) & .58 & .49 & 0 & 1 & .46 & .50 & .71 & .46 \\
\hline Woman marry man & .08 & .27 & 0 & 1 & .10 & .30 & .05 & .21 \\
\hline Income per capita $(1,000 ¥)$ & 6,790 & 7,051 & 480 & 66,667 & 7,070 & 5,560 & 6,492 & 8,358 \\
\hline Distance of wife's home & 2.58 & 1.15 & 1 & 6 & 2.56 & 1.20 & 2.61 & 1.10 \\
\hline Richer wife & 3 & .71 & 1 & 5 & 3.02 & .71 & 2.98 & .72 \\
\hline Live with parents & .64 & .48 & 0 & 1 & .81 & .39 & .46 & .50 \\
\hline
\end{tabular}

estimation results are robust to leaving "harmonious couples," with identical separate allocations, in the sample.

Useful experimental data, with husbands and wives opting for different allocations of their private $¥ 100$ endowment, are only available for a subsample of 194 couples. These couples are rather equally split across Lipu and Quanzhou (94 and 100 couples, respectively). We distinguish between three age cohorts, depending on the age of the husband (28 years or younger, 38 years or younger, and all husbands). While this distinction helps us to bolster our identification strategy (the sex ratio effect should be strongest for the youngest cohort), we also realize that men may marry older women so that it can only approximately identify which men face intensive competition on marriage markets.

In table 2 we present correlations between our three measures of bargaining power. While the two survey-based measures are significantly and positively correlated, the same is not true for the survey-based and experimental measures. Other studies have also shown that surveys and experiments can produce data that are not correlated, even if they purport to measure the same phenomenon (e.g., Glaeser et al. [2000], on the issue of measuring trust). It is not always evident which type of data is more credible - this, to some extent, is a subjective matter, and the assessment by analysts depends on the importance they attach to incentive compatibility. Of course it is also possible that bargaining power (like trust) is a multifaceted concept and that different data collection tools produce complementary measures (allowing us to probe the ro- 
TABLE 2

CORRELATION BETWEEN OUR THREE MEASUREMENTS FOR WIFE'S BARGAINING POWER

\begin{tabular}{|c|c|c|c|}
\hline & $\begin{array}{l}\text { Survey-Based } \\
\text { Bargaining Power }\end{array}$ & $\begin{array}{l}\text { Woman } \\
\text { Handles } \\
\text { Finance }\end{array}$ & $\begin{array}{l}\text { Dummy: Joint } \\
\text { Allocation } \\
\text { Is the Same as } \\
\text { Wife's Choice }\end{array}$ \\
\hline Survey-based bargaining power & 1 & & \\
\hline Woman handles finance & .36 & 1 & \\
\hline \multicolumn{4}{|l|}{ Dummy: joint allocation is the same } \\
\hline as wife's choice & .019 & .063 & 1 \\
\hline
\end{tabular}

bustness of our findings in a natural manner by comparing outcomes across measures).

Following the literature, we control for various demographic and economic variables that are associated with the division of bargaining power within the household. These variables are contained in the bottom of table 1 and include age of the husband, age difference between wife and husband (with negative values indicating that the male is older than the female), education level of the husband (measured in years of schooling), and education difference between the spouses (where, again, negative values indicate that the man has received more years of schooling). We also measure whether the couple has a son, lives with any of its parents, and, more specifically, whether it lives under the same roof as the parents of the wife (which is unusual in China but does occur in $8 \%$ of the couples in our sample). Adopting a literal translation from Chinese, the latter variable is called "woman marry man."

We also include an income measure and a variable indicating the wealth of the wife's parents relative to that of her husband's ("richer wife"). Finally, we control for distance between the couple's residence and the home of the wife's parents. We realize that some of these variables are potentially endogenous in bargaining power models and may represent outcomes of marriage market matching. Rather than instrumenting for these variables, we test whether the results that follow depend on the inclusion of any of the controls, as a robustness analysis.

To further analyze the survey-based bargaining variables, we first estimate the following ordinary least squares model:

$$
\mathrm{FBP}_{i j}=\alpha+\beta \mathrm{SR}_{j}+\gamma \boldsymbol{X}_{i j}+\varepsilon_{i j}
$$

where $\mathrm{FBP}_{i j}$ measures female bargaining power in household $i$ in county $j(j=$ 1,2 ), SR represents the local sex ratio in referent age groups (data taken from the fifth national census in 2000, as shown in fig. 1), $\boldsymbol{X}$ is a vector of controls, and $\varepsilon$ is a random error term. To capture that the sex ratio varies across 
cohorts, we estimate this model for the pooled data (using data for all age groups) and also consider subsamples in which the husband is younger than or equal to either 28 or 38 years old. As discussed, we expect the impact of female scarcity on bargaining power to be especially pronounced for "young" cohorts, growing up in an era with the OCP in effect. To explore how sex ratios affect the bargaining power as measured in our bargaining experiment, we also estimate a series of probit models. The binary dependent variable in these models indicates whether the joint choice coincides with the preference of either husband or wife.

While we believe it is reasonable to assume that (lagged) sex ratios are exogenous to current bargaining power, we also provide a robustness analysis and estimate an instrumental variable (IV) model. Taking the share of ethnic minorities (EM) in the population as an (excluded) instrument for the sex ratio, we regress female bargaining power on predicted sex ratios $\left(\mathrm{SR}^{*}\right)$ in the second stage:

$$
\mathrm{FBP}_{i j}=\alpha+\beta \mathrm{SR}_{j}^{*}+\gamma \boldsymbol{X}_{i j}+\varepsilon_{i j}
$$

where

$$
\mathrm{SR}_{j}^{*}=\pi+v \mathrm{EM}_{j}+\phi \boldsymbol{X}_{i j}+\nu_{j} .
$$

In (3), $\nu_{j}$ is a random error term. Since we have access to only one excluded instrument, we cannot test whether the overidentification assumption is satisfied (e.g., the model does not produce a Hansen $J$-test statistic). In what follows we simply assume the overidentification restriction is satisfied, or that the share of ethnic minorities is not correlated with the error term of the household bargaining model (2). This seems plausible.

However, it is evident that there are fundamental limitations to our ability to "nail" the effect of sex ratios on bargaining power, because we only have access to data from only two counties, and many other factors could be affecting differences between these counties. We are unable to control for countyspecific factors because these would be collinear with our sex ratio measure. We emphasize that it is an open question whether the results are robust to including additional counties, so the current set of results should be regarded as a set of correlations. However, we also mention that the two counties are from the same prefecture of the same province and located relatively close together - across many dimensions Lipu and Quanzhou are similar. Moreover, we have access to data from different age cohorts - affected differently by the $\mathrm{OCP}$ - to complement the results, adding some credibility to our main findings. 


\section{Empirical Results}

Tables 3 and 4 summarize our main results. In table 3, we present correlations between sex ratios and survey-based measures of bargaining power, for different age cohorts. The results suggest a positive correlation between sex ratios and female bargaining power (the one exception is in col. 1, for which we have only 45 observations). Using the complete sample, a 1 standard deviation increase in the sex ratio $\left(\sigma_{\mathrm{SR}}=0.14\right)$ translates into one-eighth of a standard deviation increase in female bargaining power and into approximately onethird of a standard deviation increase in the probability of the wife handling financial issues. As expected, the sex ratio coefficient of the "woman handles finance" variable increases as the cohorts are younger (as husbands have grown

TABLE 3

SURVEY-BASED EVIDENCE: HIGH SEX RATIOS INCREASE FEMALE BARGAINING POWER

\begin{tabular}{|c|c|c|c|c|c|c|}
\hline & \multicolumn{3}{|c|}{ Bargaining Power } & \multicolumn{3}{|c|}{ Woman Handles Finance } \\
\hline & $\begin{array}{l}\text { Husband } \\
\text { Age } \leq 28 \\
\text { Years }\end{array}$ & $\begin{array}{l}\text { Husband } \\
\text { Age } \leq 38 \\
\text { Years }\end{array}$ & $\begin{array}{l}\text { All Age } \\
\text { Cohorts }\end{array}$ & $\begin{array}{c}\text { Husband } \\
\text { Age } \leq 28 \\
\text { Years }\end{array}$ & $\begin{array}{c}\text { Husband } \\
\text { Age } \leq 38 \\
\text { Years }\end{array}$ & $\begin{array}{l}\text { All Age } \\
\text { Cohorts }\end{array}$ \\
\hline \multicolumn{7}{|l|}{ Variable: } \\
\hline Sex ratio & $\begin{array}{l}-.647 \\
(1.026)\end{array}$ & $\begin{array}{l}1.255^{\star} \\
(.665)\end{array}$ & $\begin{array}{l}1.205^{\star} \\
(.622)\end{array}$ & $\begin{array}{l}1.06^{\star \star \star} \\
(.182)\end{array}$ & $\begin{array}{l}.677^{\star \star \star} \\
(.124)\end{array}$ & $\begin{array}{l}.595^{\star \star \star} \\
(.119)\end{array}$ \\
\hline Age of husband & $\begin{array}{l}.00947 \\
(.118)\end{array}$ & $\begin{array}{c}-.00995 \\
(.0309)\end{array}$ & $\begin{array}{c}.0181 \\
(.0204)\end{array}$ & $\begin{array}{c}-.061^{\star \star \star} \\
(.0219)\end{array}$ & $\begin{array}{c}.00901 \\
(.00620)\end{array}$ & $\begin{array}{c}.00482 \\
(.00346)\end{array}$ \\
\hline Age difference & $\begin{array}{l}.0485 \\
(.0739)\end{array}$ & $\begin{array}{c}.0283 \\
(.0580)\end{array}$ & $\begin{array}{c}.0231 \\
(.0407)\end{array}$ & $\begin{array}{l}.00361 \\
(.0172)\end{array}$ & $\begin{array}{r}-.00250 \\
(.00749)\end{array}$ & $\begin{array}{r}-.00118 \\
(.00612)\end{array}$ \\
\hline Education of husband & $\begin{array}{c}-.266^{\star} \\
(.140)\end{array}$ & $\begin{array}{c}.0369 \\
(.0459)\end{array}$ & $\begin{array}{c}.0336 \\
(.0377)\end{array}$ & $\begin{array}{c}.0375 \\
(.0418)\end{array}$ & $\begin{array}{c}.00811 \\
(.0112)\end{array}$ & $\begin{array}{c}.00844 \\
(.00910)\end{array}$ \\
\hline Education difference & $\begin{array}{c}-.0916 \\
(.0544)\end{array}$ & $\begin{array}{l}.101^{\star \star} \\
(.0438)\end{array}$ & $\begin{array}{l}.0826^{\star *} \\
(.0382)\end{array}$ & $\begin{array}{l}.0360^{\star \star} \\
(.0167)\end{array}$ & $\begin{array}{l}.0155^{\star} \\
(.00836)\end{array}$ & $\begin{array}{l}.0168^{\star \star} \\
(.00662)\end{array}$ \\
\hline Have son (dummy) & $\begin{array}{c}-.240 \\
(.448)\end{array}$ & $\begin{array}{l}.00465 \\
(.216)\end{array}$ & $\begin{array}{c}-.0779 \\
(.179)\end{array}$ & $\begin{array}{c}-.0251 \\
(.0911)\end{array}$ & $\begin{array}{c}.0138 \\
(.0396)\end{array}$ & $\begin{array}{c}.0265 \\
(.0350)\end{array}$ \\
\hline Woman marry man & $\begin{array}{c}-.174 \\
(.949)\end{array}$ & $\begin{array}{l}.807^{\star \star \star} \\
(.308)\end{array}$ & $\begin{array}{l}.734^{\star \star \star} \\
(.280)\end{array}$ & $\begin{array}{l}.462^{\star \star} \\
(.205)\end{array}$ & $\begin{array}{l}.130 \\
(.0842)\end{array}$ & $\begin{array}{l}.126^{*} \\
(.0659)\end{array}$ \\
\hline Income per capita & $\begin{array}{c}-.0188 \\
(.0124)\end{array}$ & $\begin{array}{r}-.026^{\star \star} \\
(.0128)\end{array}$ & $\begin{array}{c}-.0172 \\
(.0121)\end{array}$ & $\begin{array}{c}-.0069 * \star \\
(.0027)\end{array}$ & $\begin{array}{r}-.0046^{*} \\
(.0026)\end{array}$ & $\begin{array}{r}-.006^{\star \star} \\
(.0023)\end{array}$ \\
\hline Distance of wife's home & $\begin{array}{l}.185^{\star} \\
(.108)\end{array}$ & $\begin{array}{c}.0636 \\
(.112)\end{array}$ & $\begin{array}{c}.0593 \\
(.0878)\end{array}$ & $\begin{array}{c}-.0244 \\
(.0293)\end{array}$ & $\begin{array}{r}-.0320 * \\
(.0192)\end{array}$ & $\begin{array}{r}-.0292^{\star} \\
(.0157)\end{array}$ \\
\hline Richer wife & $\begin{array}{r}-.0157 \\
(.285)\end{array}$ & $\begin{array}{c}.293^{\star} \\
(.170)\end{array}$ & $\begin{array}{c}.229^{*} \\
(.128)\end{array}$ & $\begin{array}{c}.115^{\star} \\
(.0633)\end{array}$ & $\begin{array}{c}.0393 \\
(.0279)\end{array}$ & $\begin{array}{l}.0596 * \star \\
(.0231)\end{array}$ \\
\hline Live with parents & $\begin{array}{r}-1.087 \\
(.789)\end{array}$ & $\begin{array}{r}-.0777 \\
(.263)\end{array}$ & $\begin{array}{c}-.0818 \\
(.205)\end{array}$ & $\begin{array}{l}.142 \\
(.140)\end{array}$ & $\begin{array}{r}-.0419 \\
(.0485)\end{array}$ & $\begin{array}{r}-.091^{\star \star} \\
(.0386)\end{array}$ \\
\hline Constant & $\begin{array}{l}8.371^{\text {*** }} \\
(2.753)\end{array}$ & $\begin{array}{c}1.811 \\
(1.817)\end{array}$ & $\begin{array}{c}1.219 \\
(1.501)\end{array}$ & $\begin{array}{l}.00806 \\
(.647)\end{array}$ & $\begin{array}{c}-.708^{\star \star} \\
(.328)\end{array}$ & $\begin{array}{c}-.507^{\star} \\
(.261)\end{array}$ \\
\hline Observations & 45 & 214 & 290 & 40 & 196 & 271 \\
\hline$R^{2}$ & .243 & .090 & .061 & .575 & .179 & .174 \\
\hline
\end{tabular}

Note. Robust standard errors in parentheses.

$\star p<.1$.

$\star \star *<<.05$

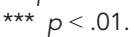


TABLE 4

EXPERIMENTAL EVIDENCE: HIGH SEX RATIOS INCREASE BARGAINING POWER OF WOMEN BORN WHEN THE ONE-CHILD POLICY WAS IN PLACE

\begin{tabular}{|c|c|c|c|c|c|c|}
\hline & \multicolumn{3}{|c|}{$\begin{array}{l}\text { Dummy 1: Joint Allocation Is the } \\
\text { Same as the Husband's Choice }\end{array}$} & \multicolumn{3}{|c|}{$\begin{array}{l}\text { Dummy 2: Joint Allocation Is the } \\
\text { Same as the Wife's Choice }\end{array}$} \\
\hline & $\begin{array}{l}\text { Husband } \\
\text { Age } \leq 28\end{array}$ & $\begin{array}{l}\text { Husband } \\
\text { Age } \leq 38\end{array}$ & $\begin{array}{l}\text { All Age } \\
\text { Cohorts }\end{array}$ & $\begin{array}{l}\text { Husband } \\
\text { Age } \leq 28\end{array}$ & $\begin{array}{l}\text { Husband } \\
\text { Age } \leq 38\end{array}$ & $\begin{array}{l}\text { All Age } \\
\text { Cohorts }\end{array}$ \\
\hline \multicolumn{7}{|l|}{ Variable: } \\
\hline Sex ratio & $\begin{array}{l}-3.454^{\star \star} \\
(1.640)\end{array}$ & $\begin{array}{l}-.488 \\
(.819)\end{array}$ & $\begin{array}{l}-.337 \\
(.776)\end{array}$ & $\begin{array}{l}4.397^{\star \star} \\
(1.920)\end{array}$ & $\begin{array}{l}.0919 \\
(.822)\end{array}$ & $\begin{array}{r}-.0965 \\
(.786)\end{array}$ \\
\hline Age of husband & $\begin{array}{l}.416^{\star *} \\
(.195)\end{array}$ & $\begin{array}{l}.0326 \\
(.0345)\end{array}$ & $\begin{array}{r}-.00169 \\
(.0219)\end{array}$ & $\begin{array}{l}-.663^{\star \star \star} \\
(.254)\end{array}$ & $\begin{array}{l}.0167 \\
(.0347)\end{array}$ & $\begin{array}{l}.0232 \\
(.0226)\end{array}$ \\
\hline Age difference & $\begin{array}{l}.160 \\
(.171)\end{array}$ & $\begin{array}{l}.0535 \\
(.0505)\end{array}$ & $\begin{array}{l}.0203 \\
(.0413)\end{array}$ & $\begin{array}{l}.543^{\star \star} \\
(.226)\end{array}$ & $\begin{array}{c}-.00862 \\
(.0507)\end{array}$ & $\begin{array}{l}.0133 \\
(.0386)\end{array}$ \\
\hline Education of husband & $\begin{array}{l}.394 \\
(.252)\end{array}$ & $\begin{array}{l}.0780 \\
(.0677)\end{array}$ & $\begin{array}{l}.0528 \\
(.0552)\end{array}$ & $\begin{array}{l}-.176 \\
(.251)\end{array}$ & $\begin{array}{r}-.00739 \\
(.0644)\end{array}$ & $\begin{array}{l}.00640 \\
(.0531)\end{array}$ \\
\hline Education difference & $\begin{array}{l}.0267 \\
(.118)\end{array}$ & $\begin{array}{l}.0402 \\
(.0617)\end{array}$ & $\begin{array}{l}.0136 \\
(.0452)\end{array}$ & $\begin{array}{c}-.0128 \\
(.160)\end{array}$ & $\begin{array}{l}.00167 \\
(.0602)\end{array}$ & $\begin{array}{l}.0216 \\
(.0456)\end{array}$ \\
\hline Have son (dummy) & $\begin{array}{l}-.287 \\
(.624)\end{array}$ & $\begin{array}{l}.367 \\
(.228)\end{array}$ & $\begin{array}{c}.304 \\
(.202)\end{array}$ & $\begin{array}{c}.712 \\
(.808)\end{array}$ & $\begin{array}{r}-.399 * \\
(.233)\end{array}$ & $\begin{array}{c}-.250 \\
(.200)\end{array}$ \\
\hline Woman marry man & & $\begin{array}{l}.116 \\
(.532)\end{array}$ & $\begin{array}{l}.00429 \\
(.430)\end{array}$ & & $\begin{array}{c}-.929 \\
(.644)\end{array}$ & $\begin{array}{r}-.842^{\star} \\
(.476)\end{array}$ \\
\hline Income per capita & $\begin{array}{l}-.0002 \\
(.00004)\end{array}$ & $\begin{array}{c}-.00001 \\
(.00002)\end{array}$ & $\begin{array}{c}-.00001 \\
(.00002)\end{array}$ & $\begin{array}{r}-.00009 \\
(.00013)\end{array}$ & $\begin{array}{r}-.000003 \\
(.00002)\end{array}$ & $\begin{array}{r}-6.36 \mathrm{E}-06 \\
(.000017)\end{array}$ \\
\hline Distance of wife's home & $\begin{array}{l}.153 \\
(.194)\end{array}$ & $\begin{array}{l}.109 \\
(.112)\end{array}$ & $\begin{array}{c}.0666 \\
(.0928)\end{array}$ & $\begin{array}{c}-.418^{\star} \\
(.235)\end{array}$ & $\begin{array}{c}-.0596 \\
(.113)\end{array}$ & $\begin{array}{r}-.0521 \\
(.0927)\end{array}$ \\
\hline Richer wife & $\begin{array}{r}-.109 \\
(.379)\end{array}$ & $\begin{array}{c}-.0982 \\
(.164)\end{array}$ & $\begin{array}{c}-.0770 \\
(.130)\end{array}$ & $\begin{array}{l}1.467^{\star \star} \\
(.740)\end{array}$ & $\begin{array}{r}-.109 \\
(.169)\end{array}$ & $\begin{array}{c}-.0793 \\
(.136)\end{array}$ \\
\hline Live with parents & $\begin{array}{l}.0948 \\
(.870)\end{array}$ & $\begin{array}{c}-.00298 \\
(.267)\end{array}$ & $\begin{array}{l}.122 \\
(.221)\end{array}$ & $\begin{array}{l}1.661^{*} \\
(.988)\end{array}$ & $\begin{array}{c}-.159 \\
(.275)\end{array}$ & $\begin{array}{c}-.182 \\
(.226)\end{array}$ \\
\hline Constant & $\begin{array}{r}-10.70^{\star *} \\
(5.218)\end{array}$ & $\begin{array}{c}-1.369 \\
(2.016)\end{array}$ & $\begin{array}{c}-.338 \\
(1.730)\end{array}$ & $\begin{array}{r}9.070 * \\
(5.445)\end{array}$ & $\begin{array}{l}-.110 \\
(2.068)\end{array}$ & $\begin{array}{l}-.271 \\
(1.788)\end{array}$ \\
\hline Observations & 31 & 136 & 184 & 31 & 136 & 184 \\
\hline Pseudo- $R^{2}$ & .321 & .037 & .023 & .465 & .035 & .034 \\
\hline
\end{tabular}

Note. Robust standard errors in parentheses.

* $p<.1$.

** $p<.05$.

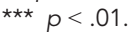

up and matured in an environment with few girls). Nevertheless, the results do not exclude the possibility that older cohorts of husbands are also affected by the scarcity of younger women in their environment, perhaps because it is not unusual for older husbands to marry younger brides.

Most of the other covariates correlate as expected with our proxies of bargaining power. For example, if women are better educated than men ("education difference") their subjective bargaining power, as well as the probability of handling finances, tends to increase. Similarly, if the household moves in with the parents of the bride - rather than the groom, as customary - the bargaining power of the wife tends to improve, and the likelihood of her handling 
finances goes up. We also find that both proxies of female bargaining power increase as the wife's parents are wealthier ("richer wife") but not with household income ("income per capita"). In fact, the reverse appears true for the latter variable. As distance to the wife's parents increases, the probability of her handling household finances deteriorates. For our sample, we find no evidence that the age or education of the husband or the age difference between the spouses matter for the distribution of intrahousehold bargaining power.

In table 4, we report the results of an analysis of our experimental data. They are consistent with the survey-based evidence presented above. Specifically, for cohorts born with the OCP in effect (i.e., with husbands 28 years or younger), or those with high sex ratios in Quanzhou, we find that the husband's preference is less likely to coincide with the couple's joint choice. Moreover, and in contrast, it is more likely that the collective choice coincides with the preferences of the wife. We find no significant differences for couples in which the husband is older than 28 years (or couples born before the OCP was implemented). The magnitude of the empowerment effect on young couples is economically, as well as statistically, significant. A look at the relevant marginal effects suggests that a 1 standard deviation increase in the sex ratio increases the probability that a woman's preferences dominate collective decision making by $15 \%$. Similarly, the probability that her husband's preferences dominate goes down by nearly $17 \%$. Since local sex ratios in rural China reach values exceeding 1.5 , or 3 standard deviations greater than the natural sex ratio, the preferences of women in these localities dominate those of their husbands for the types of decisions captured in our experiment.

In table 5, we summarize the results of an extensive robustness analysis. We only report the coefficient of interest (associated with the sex ratio), but in some of these models a full vector of controls was included. We first estimate parsimonious models including only sex ratios and a constant. The associated coefficient and (robust) standard errors are reported in the top three rows (representing the three different proxies of bargaining power). Across the board, these results are comparable to those reported in tables 3 and 4 . We have also estimated models where we consider subsamples of couples that more or less agree on the division of intrahousehold bargaining power (i.e., including only households where the sum of the estimates of own bargaining power is a value close to 10). Finally, for the "woman handles finance" variable, with its five possible outcomes, we have estimated a series of ordered probit models. The results of all these specifications are very similar to those presented earlier.

Tables 6 and 7 summarize the results of another robustness analysis where we estimated an IV model (instrumenting sex ratios with the share of ethnic minorities). The weak identification and underidentification test statistics 
TABLE 5

ROBUSTNESS ANALYSIS

\begin{tabular}{lccc}
\hline & Husband & Husband & All Age \\
Sex Ratio & Age $\leq 28$ & Age $\leq 38$ & Cohorts \\
\hline Parsimonious model explaining bargaining power in survey & -.353 & $1.30^{\star \star}$ & $.995^{\star \star}$ \\
& $(.708)$ & $(.536)$ & $(.483)$ \\
Parsimonious model explaining "woman handles finance" & $.701^{\star \star \star}$ & $.517^{\star \star \star}$ & $.404^{\star \star \star}$ \\
& $(.224)$ & $(.123)$ & $(.116)$ \\
Parsimonious model explaining bargaining power in experiment & $2.22^{\star}$ & .389 & .146 \\
Subsample analysis: near agreement on bargaining power & $(1.15)$ & $(.609)$ & $(.585)$ \\
(sum of perceived shares $<11$ ) & & & \\
& -5.18 & $2.19^{\star}$ & $2.53^{\star \star}$ \\
Ordered probit explaining "woman handles finance" & 3.94 & $(1.32)$ & $(1.20)$ \\
& $5.520^{\star \star \star}$ & $2.716^{\star \star \star}$ & $2.383^{\star \star \star}$ \\
& $(1.148)$ & $(.507)$ & $(.491)$ \\
\hline
\end{tabular}

Note. Robust standard errors in parentheses.

$\star p<.1$.

$* * p<.05$.

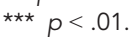

reject their null hypotheses at the $99 \%$ level, suggesting that the instrument is adequate to identify the equation. While the coefficients in the second stage are larger than in the simple models in tables 3 and 4, we find that the results are quite robust in a qualitative sense. Note that our IV results should provide an upper bound of the true effect if the ethnic minority instrument is positively correlated with omitted variables with the same sign as sex ratios in the bargaining model (Pande and Udry 2005).

\section{Discussion and Conclusion}

In this article we seek to merge two literatures: the consequences of high sex ratios and the determinants of female bargaining power. Female empowerment has important economic consequences and has become an important policy objective. A growing literature suggests that transferring resources to women enhances their bargaining position in the household (Ashraf et al. 2010). We suggest another channel might also matter in the battle of the sexes, at least in countries with unbalanced sex ratios. Our main result is a positive correlation between sex ratios and our measures of female bargaining power in China. Specifically, women have stronger bargaining positions in the household when they are scarce on the "marriage market." We believe this is one of the first direct tests of a relation between sex ratios and bargaining power (for another study, refer to Bloch and Rao [2002]). ${ }^{8}$ Our main result is consistent with earlier indirect tests by Angrist (2002) and Chiappori et al. (2002) focusing on economic variables such as labor supply.

${ }^{8}$ Bloch and Rao (2002) study the use of domestic violence as a bargaining instrument to extract larger transfers from the bride's family. Better marriage conditions for the husband affect the dowry and his willingness to resort to violence. 
TABLE 6

SURVEY-BASED EVIDENCE: INSTRUMENTAL VARIABLE APPROACH (TWO-STAGE LEAST SQUARES)

\begin{tabular}{|c|c|c|c|c|c|c|}
\hline & \multicolumn{3}{|c|}{ Bargaining Power } & \multicolumn{3}{|c|}{ Woman Handles Finance } \\
\hline & $\begin{array}{c}\text { Husband } \\
\text { Age } \leq 28 \\
\text { Years }\end{array}$ & $\begin{array}{c}\text { Husband } \\
\text { Age } \leq 38 \\
\text { Years }\end{array}$ & $\begin{array}{l}\text { All Age } \\
\text { Cohorts }\end{array}$ & $\begin{array}{c}\text { Husband } \\
\text { Age } \leq 28 \\
\text { Years }\end{array}$ & $\begin{array}{c}\text { Husband } \\
\text { Age } \leq 38 \\
\text { Years }\end{array}$ & $\begin{array}{l}\text { All Age } \\
\text { Cohorts }\end{array}$ \\
\hline \multicolumn{7}{|l|}{ Second-stage results: } \\
\hline Sex ratio & $\begin{array}{l}-.868 \\
(1.075)\end{array}$ & $\begin{array}{l}2.084^{\star \star} \\
(1.012)\end{array}$ & $\begin{array}{l}3.191^{\star \star} \\
(1.250)\end{array}$ & $\begin{array}{l}1.045^{\star \star \star} \\
(.167)\end{array}$ & $\begin{array}{l}1.098^{\star \star \star} \\
(.204)\end{array}$ & $\begin{array}{l}1.364^{\star \star \star} \\
(.254)\end{array}$ \\
\hline $\begin{array}{l}\text { Controls } \\
R^{2}\end{array}$ & $\begin{array}{l}\text { Yes } \\
.242\end{array}$ & $\begin{array}{l}\text { Yes } \\
.084\end{array}$ & $\begin{array}{l}\text { Yes } \\
.033\end{array}$ & $\begin{array}{l}\text { Yes } \\
.575\end{array}$ & $\begin{array}{l}\text { Yes } \\
.142\end{array}$ & $\begin{array}{l}\text { Yes } \\
.076\end{array}$ \\
\hline \multicolumn{7}{|l|}{ First-stage results: } \\
\hline Ethnic minorities & $\begin{array}{c}-2.54^{\star \star \star} \\
(.089)\end{array}$ & $\begin{array}{c}-1.45^{\star \star \star} \\
(.108)\end{array}$ & $\begin{array}{c}-1.04^{\star \star \star} \\
(.092)\end{array}$ & $\begin{array}{c}-2.55^{\star \star \star} \\
(.005)\end{array}$ & $\begin{array}{c}-1.41 \star \star \star \\
(.111)\end{array}$ & $\begin{array}{c}-1.00 * \star \star \\
(.093)\end{array}$ \\
\hline Included instruments & Yes & Yes & Yes & Yes & Yes & Yes \\
\hline $\begin{array}{l}\text { Partial } F \\
\text { Kleibergen-Paap rk LM }\end{array}$ & 815 & 181 & 127 & 626 & 162 & 116 \\
\hline (p-value) & .000 & .000 & .000 & .000 & .000 & .000 \\
\hline$N$ & 45 & 214 & 290 & 40 & 196 & 271 \\
\hline
\end{tabular}

Note. Robust standard errors in parentheses.

** $p<.05$.

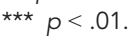

We end with a few words of caution. First, our measures of bargaining power are not perfect. The survey-based measures are hypothetical, and various confounding factors may compromise our experimental measure. However, we note it is comforting that the main results are consistent across the various measures, suggesting that, while arguably imperfect, these measures are capturing some relevant variation in bargaining power.

Second, one of our important identifying assumptions is that sex ratios vary across Chinese counties, reflecting the share of ethnic minorities unaffected by the regulations of the OCP. We document that variation in sex ratios, over both time and space, is consistent with the assumption that sex ratios are determined by the interplay between national policies, local enforcement of the OCP, and the ethnic composition of local communities. We believe the resulting variation in sex ratios is exogenous to variables such as female empowerment, so that county-level sex ratios are proper explanatory variables in models explaining female bargaining power. This reasoning is reinforced by the following thought experiment. If (local average) female empowerment would affect sex ratios, then it seems plausible that greater empowerment should lead to lower sex ratios-less sex-selective abortion, neglect, and infanticide. Insofar as county-level sex ratios respond to empowerment, therefore, we may view our estimates as lower bounds of the true causal effect of high sex ratios on empowerment. Nevertheless, we also present the results of 
TABLE 7

EXPERIMENTAL EVIDENCE: INSTRUMENTAL VARIABLE APPROACH (IV PROBIT)

\begin{tabular}{|c|c|c|c|c|c|c|}
\hline & \multicolumn{3}{|c|}{$\begin{array}{l}\text { Dummy 1: Joint Allocation Is the } \\
\text { Same as the Husband's Choice }\end{array}$} & \multicolumn{3}{|c|}{$\begin{array}{l}\text { Dummy 2: Joint Allocation Is the } \\
\text { Same as the Wife's Choice }\end{array}$} \\
\hline & $\begin{array}{c}\text { Husband } \\
\text { Age } \leq 28 \\
\text { Years }\end{array}$ & $\begin{array}{c}\text { Husband } \\
\text { Age } \leq 38 \\
\text { Years }\end{array}$ & $\begin{array}{l}\text { All Age } \\
\text { Cohorts }\end{array}$ & $\begin{array}{c}\text { Husband } \\
\text { Age } \leq 28 \\
\text { Years }\end{array}$ & $\begin{array}{c}\text { Husband } \\
\text { Age } \leq 38 \\
\text { Years }\end{array}$ & $\begin{array}{l}\text { All Age } \\
\text { Cohorts }\end{array}$ \\
\hline \multicolumn{7}{|l|}{ Second-stage results: } \\
\hline Sex ratio & $\begin{array}{c}-4.024^{\star \star} \\
(1.746)\end{array}$ & $\begin{array}{c}.112 \\
(1.112)\end{array}$ & $\begin{array}{c}.529 \\
(1.324)\end{array}$ & $\begin{array}{l}4.812^{\star \star} \\
(1.881)\end{array}$ & $\begin{array}{l}-.287 \\
(1.172)\end{array}$ & $\begin{array}{c}.317 \\
(1.359)\end{array}$ \\
\hline $\begin{array}{l}\text { Controls } \\
R^{2}\end{array}$ & $\begin{array}{l}\text { Yes } \\
.242\end{array}$ & $\begin{array}{l}\text { Yes } \\
.084\end{array}$ & $\begin{array}{l}\text { Yes } \\
.033\end{array}$ & $\begin{array}{l}\text { Yes } \\
.575\end{array}$ & $\begin{array}{l}\text { Yes } \\
.142\end{array}$ & $\begin{array}{l}\text { Yes } \\
.076\end{array}$ \\
\hline \multicolumn{7}{|l|}{ First-stage results: } \\
\hline Ethnic minorities & $\begin{array}{c}-2.55^{\star \star \star} \\
(.091)\end{array}$ & $\begin{array}{c}-1.46^{\star \star \star} \\
(.123)\end{array}$ & $\begin{array}{c}-1.09^{\star \star \star} \\
(.112)\end{array}$ & $\begin{array}{c}-2.55^{\star \star \star} \\
(.138)\end{array}$ & $\begin{array}{c}-1.46^{\star \star \star} \\
(.115)\end{array}$ & $\begin{aligned}-1.09 * \star \star \\
(.101)\end{aligned}$ \\
\hline $\begin{array}{l}\text { Included instruments } \\
\text { Wald test of exogeneity }\end{array}$ & Yes & Yes & Yes & Yes & Yes & Yes \\
\hline$\left(\chi^{2}, \operatorname{Pr}>\chi^{2}\right)$ & 3.65 & .63 & .62 & .70 & .24 & .14 \\
\hline$p$-value & .06 & .42 & .43 & .40 & .62 & .71 \\
\hline$N$ & 31 & 136 & 184 & 31 & 136 & 184 \\
\hline
\end{tabular}

Note. Robust standard errors in parentheses.

** $p<.05$.

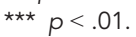

an IV model in which sex ratios are endogenous, and that model's results support our main findings.

Third, we emphasize that our results are suggestive because of inherent shortcomings of our identification strategy. We present correlations between sex ratios and measures of bargaining power, but our sample contains data from only two counties. Several factors may vary across these counties, and we cannot control for such factors (as county-level controls would be collinear with our sex ratio data). Of course it is comforting to note that our results for different age cohorts tend to match those focusing on variation across space, but it is clear that additional analysis (based on a larger number of counties) should complement the analysis on these pages. Our findings are not the final word on the interaction between national policy and ethnic composition.

\section{References}

Abramitzky, Ran, Leah P. Boustan, and Katherine Eriksson. 2012. "A Nation of Immigrants: Assimilation and Economic Outcomes in the Age of Mass Migration." NBER Working Paper 18011, National Bureau of Economic Research, Cambridge, MA.

Angrist, Josh. 2002. "How Do Sex Ratios Affect Marriage and Labor Markets? Evidence from America's Second Generation." Quarterly Journal of Economics 117, no. 3:9971038. 
Ashraf, Nava, Dean Karlan, and Wesley Yin. 2010. "Female Empowerment: Impact of a Commitment Savings Product in the Philippines." World Development 38, no. 3: 333-44.

Bateman, Ian, and Alistair Munro. 2005. "An Experiment on Risky Choice amongst Households." Economic Journal 115, no. 502:176-89.

Becker, Gary S. 1973. "A Theory of Marriage." Pt. 1. Iournal of Political Economy 81:813-46.

- 1974. "A Theory of Marriage." Pt. 2. Lournal of Political Economy 82:S11-S26.

Bloch, Francis, and Vijayendra Rao. 2002. "Terror as a Bargaining Instrument: A Case Study of Dowry Violence in Rural India." American Economic Review 92, no. 4: 029-43.

Brown, Philip H. 2009. "Dowry and Intrahousehold Bargaining: Evidence from China." Iournal of Human Resources 44, no. 1:25-46.

Bulte, Erwin H., Xiaobo Zhang, and Nico Heerink. 2011. "China’s One-Child Policy and 'The Mystery of Missing Women': Ethnic Minorities and Male-Biased Sex Ratios." Oxford Bulletin of Economics and Statistics 73, no. 1:21-39.

Carlsson, Fredrik, Haoran He, Peter Martinsson, Ping Qin, and Matthias Sutter. 2012. "Household Decision Making in Rural China: Using Experiments to Estimate the Influences of Spouses." Iournal of Economic Behavior and Oroanization 84, no. 2:525-36.

Chattopadhyay, Raghabendra, and Esther Duflo. 2004. "Women as Policy Makers: Evidence from a Randomized Policy Experiment in India." Econometrica 72, no. 5: 1409-43.

Chiappori, Pierre-Andre, Bernard Fortin, and Guy Lacroix. 2002. "Marriage Market, Divorce Legislation, and Household Labor Supply." Iournal of Political Economy 110, no. 1:37-72.

Cox, Oliver C. 1940. "Sex Ratio and Marital Status among Negroes." American Sociolooical Review 5:937-47.

Ding, Weili, and Yuan Zhang. 2013. "When Son Is Born: The Impact of Fertility Patterns on Family Finance in Rural China." Discussion paper, Queen's University.

Doss, Cheryl. 1999. "Intrahousehold Resource Allocation in Ghana: The Impact of the Distribution of Asset Ownership within the Household." In Food Security, Diversification and Resource Management: Refocusing the Role of Agriculture? ed. G. H. Peters and J. von Braun. Aldershot: Dartmouth.

Duflo, Esther. 2003. "Grandmothers and Granddaughters: Old-Age Pensions and Intrahousehold Allocation in South Africa." World Bank Economic Review 17:1-25.

Easterlin, Richard A. 1961. "Influences in European Overseas Emigration before World War I." Economic Develomment and Cultural Chanoe 9 (April): 331-51.

Gitter, Seth R., and Bradford L. Barham. 2008. "Women's Power, Conditional Cash Transfers, and Schooling in Nicaragua." World Bank Economic Review 22, no. 2: 271-90.

Glaeser, Edward L., David I. Laibson, José A. Scheinkman, and Christine L. Soutter. 2000. "Measuring Trust." Ouarterly Journal of Economics 115, no. 3:811-46.

Groves, Ernest R., and William F. Ogburn. 1928. American Marriage and Family Relationships. New York: Henry Holt \& Co. 
Harrison, Glenn W., and John A. List. 2004. "Field Experiments." Lournal of Economic Literature 42, no. 4:1009-55.

Hoddinott, John, and Lawrence Haddad. 1995. "Does Female Income Share Influence Household Expenditures? Evidence from Cote d'Ivoire.” Oxford Bulletin of Economics and Statistics 57, no. 1:77-96.

Klasen, Stephan, and Claudia Wink. 2002. "A Turning Point in Gender Bias in Mortality? An Update on the Number of Missing Women." Population and Development Review 28, no. 2:285-312.

Li, Hongbin, and Junsen Zhang. 2007. "Do High Birth Rates Hamper Economic Growth?" Review of Economics and Statistics 89, no. 1:110-17.

Luhan, Wolfgang J., Martin G. Kocher, and Matthias Sutter. 2009. "Group Polarization in the Team Dictator Game Reconsidered." Experimental Economics 12, no. 1: 26-41.

Lundberg, Shelly J., Robert A. Pollak, and Terence J. Wales. 1997. "Do Husbands and Wives Pool Their Resources? Evidence from the United Kingdom Child Benefit." Iournal of Human Resources 32, no. 3:463-80.

NBS (National Bureau of Statistics). 2009. "Statistical Communiqué of the People's Republic of China on the 2008 National Economic and Social Development." NBS, Beijing. http://www.stats.gov.cn/english/NewsEvents/200902/t20090226 _26111.html.

Pande, Rohini, and Christopher Udry. 2005. "Institutions and Development: A View from Below." In Proceedings of the 9th World Congress of the Econometric Society, ed. R. Blundell, W. Newey, and T. Persson. Cambridge: Cambridge University Press.

Qian, Nancy. 2008. "Missing Women and the Price of Tea in China: The Effect of Sex-Specific Earnings on Sex Imbalance." Quarterly Journal of Economics 123, no. 3: 1251-85.

Quisumbing, Agnes. 1994. "Gender Differences in Agricultural Productivity: A Survey of Empirical Evidence." Education and Social Policy Discussion Paper 36, World Bank, Washington, DC.

Sen, Amartya. 1992. "Missing Women." British Medical Journal 304, no. 6827:58788.

Senauer, Benjamin, Marito Garcia, and Elizabeth Jacinto. 1988. "Determinants of the Intrahousehold Allocation of Food in the Rural Philippines." American Journal of Agricultural Economics 70, no. 1:170-80.

Thomas, Duncan. 1990. "Intra-household Resource Allocation: An Inferential Approach." Iournal of Human Resources 25, no. 4:635-64.

- 1993. "The Distribution of Income and Expenditure within the Household." Annales de Economie et de Statistiques 29:109-36.

Wei, Shang-Jin, and Xiaobo Zhang. 2011a. "The Competitive Saving Motive: Evidence from Rising Sex Ratios and Savings in China." Iournal of Political Economy 119, no. 3:511-64.

. 2011b. "Sex Ratios, Entrepreneurship, and Economic Growth in the People's Republic of China.” NBER Working Paper 16800, National Bureau of Economic Research, Cambridge, MA. 